\title{
Rancang Bangun Sistem Pendukung Keputusan Penentuan Indeks Lingkungan pada Jaringan Sensor Nirkabel
}

\author{
Muhammad Naufal Prasetyo ${ }^{1)}$, Oky Dwi Nurhayati2), Eko Didik Widianto ${ }^{2)}$ \\ Program Studi Sistem Komputer, Fakultas Teknik, Universitas Diponegoro \\ Jalan Prof. Soedarto, SH, Tembalang, Semarang, Indonesia
}

\begin{abstract}
Nowadays, the major environmental issues that faced by campus stakeholders is climate change mitigation and campus sustainability. Universities of the world, including in Indonesia, efforts to reduce carbon emissions, manage and improve the development of a sustainable campus. The need for the information of environmental data in the form of gas concentration $\mathrm{CO}, \mathrm{NO2}$, particulate matter, temperature, humidity and luminous intensity accurately and real-time using a wireless sensor network. This data is processed using a decision support system to determine the environmental index. This research aims to design a decision support system to determine environmental index on wireless sensor networks.
\end{abstract}

This decision support system is developed using PHP programming language, CodeIgniter framework and MySQL database. The method that used is Simple Additive Weighting (SAW) based on the order of several calculation requirements, the calculation of daily values, the daily scores, geomean of daily scores and weight for each parameter, which in finally is used to determine the environmental index.

The results of this research is to show the quality of the environmental index, the graph visualization of environmental index, data for each parameter and the solutions based on index so that it can provide environment information for civitas academica and accurate feedback for decision makers or campus policy to formulate and evaluate policies in a sustainable campus development.

Keywords: decision support system, campus environment, environmental index, wireless sensor network, simple additive weighting

\section{PENDAHULUAN}

$\mathrm{S}$ aat ini, isu lingkungan utama yang dihadapi oleh pemangku kepentingan kampus adalah mitigasi perubahan iklim dan ketahanan/keberlanjutan kampus. Universitas dunia, termasuk di Indonesia, melakukan upaya untuk mengurangi emisi karbon dan mengelola serta meningkatkan pengembangan kampus yang berkelanjutan.

Skema pengembangan kampus yang berkelanjutan melibatkan 3 aspek indikator, yaitu lingkungan, (research) ekonomi dan (society) pendidikan ${ }^{[1]}$. Ketiga aspek tersebut menjadi pilar serta saling terkoneksi dan bersifat multidimensi untuk mewujudkan kampus unggul yang berwawasan lingkungan, yaitu meliputi penggunaan dan pengelolaan energi yang efisien, riset yang berwawasan lingkungan dan kepedulian sivitas akademika.

Salah satu metrik yang digunakan untuk mengevaluasi pengembangan kampus yang sustain dan berwawasan lingkungan adalah UI GreenMetric [2]. UI GreenMetric mempunyai 5 kriteria dalam mengevaluasi sustainabilitas pengembangan kampus, yaitu penataan lingkungan, mitigasi perubahan iklim dan konservasi energi, pengelolaan sampah, konservasi air, dan transportasi yang ramah lingkungan [3]. Metode evaluasi dilakukan secara deskriptif dan kualitatif serta dilakukan pembobotan dan penghitungan skor. Metrik tersebut mengevaluasi strategi/kebijakan dan upaya kampus untuk mewujudkan kampus hijau. Indikator yang dinilai antara lain dalam penataan lingkungan dan infrastruktur kampus terkait dengan penggunaan listrik, jumlah mobil/motor dan jumlah sepeda, penggunaan perangkat hemat energi, kebijakan penggunaan energi terbarukan, kebijakan mengurangi emisi gas dan kebijakan transportasi untuk membatasi jumlah kendaraan dalam kampus.

Sistem jaringan sensor nirkabel merupakan sebuah sistem jaringan yang dapat memberikan data-data lingkungan berupa gas karbon monoksida, gas nitrogen dioksida, partikulat, suhu, kelembapan udara dan intensitas cahaya. Data yang didapatkan untuk menentukan indeks/skor setiap parameter tersebut harus akurat. Parameter tersebut akan menghasilkan gejala yang dapat menimbulkan akibat. Tentu saja akibat yang ditimbulkan ini membutuhkan solusi yang dapat digunakan sebagai hasil kebijakan. Dampak dari hasil kebijakan tersebut juga perlu terukur dengan akurat.

Salah satu teknologi yang mampu menentukan dan mengukur dengan akurat adalah sistem pendukung keputusan. Sistem pendukung keputusan merupakan proses alternatif tindakan untuk mencapai tujuan atau sasaran tertentu. Tujuan penelitian ini adalah merancang dan membangun sistem pendukung keputusan untuk penentuan indeks lingkungan dan kriteria dalam pemberian informasi lingkungan bagi masyarakat lingkungan kampus dan masukan yang akurat bagi pengambil keputusan/kebijakan kampus serta menerapkan metode Simple Additive Weighting (SAW) sebagai pengambil keputusan. Metode ini digunakan karena merupakan metode yang banyak digunakan dalam pengambilan keputusan yang memiliki banyak atribut.

Penelitian terdahulu terkait dengan penelitian yang akan dilakukan oleh penulis adalah penelitian dari Ghazali [4], berjudul Sistem Pendukung Keputusan Penentuan Kualitas Air Sungai dengan Metode Fuzzy Mamdani. Pada penelitian ini dilakukan pembuatan sistem pendukung keputusan kualitas air sungai dengan metode Fuzzy Mamdani. Masukan yang dibutuhkan adalah parameter uji kualitas air yang terdiri dari parameter fisika dan kimia sehingga dapat ditentukan ke dalam empat kelas yaitu baik, tercemar ringan, tercemar sedang, dan tercemar berat.

Untuk menghindari pembahasan di luar penelitian, penulis memberi batasan masalah antara lain, pembuatan sistem hanya berada di lokasi Universitas Diponegoro, pembuatan sistem digunakan untuk pengukuran indeks lingkungan, parameter lingkungan yang akan diukur berupa gas karbon monoksida, gas nitrogen dioksida, partikulat, suhu, kelembapan udara dan intensitas cahaya, serta sistem pendukung keputusan lebih ditekankan pada penerapan metode Simple Additive Weighting (SAW) untuk perhitungan kepastian. 


\section{METODE PENGEMBANGAN}

Metode Rapid Application Development (RAD) adalah sebuah model proses perkembangan perangkat lunak sekuensial linier yang menekankan pada siklus perkembangan cepat dengan menggunakan pendekatan konstruksi berbasis komponen sehingga apabila kebutuhan dipahami dengan baik, maka sistem fungsional yang utuh dapat diselesaikan dalam waktu kira-kira 60 sampai dengan 90 hari ${ }^{[5]}$. Fase dalam RAD dibagi menjadi empat, yaitu fase perencanaan syarat-syarat, fase desain pengguna, fase konstruksi, dan fase pelaksanaan ${ }^{[6]}$.

Pada fase perencanaan syarat-syarat, pengguna tingkat tinggi memutuskan fungsi apa saja yang harus difiturkan oleh aplikasi sesuai dengan analisis kebutuhan meliputi pembuat keputusan, nilai bamut, nilai bobot, nilai harian, nilai skor harian, rerata ukur skor harian, nilai saw, dan penghitungan indeks lingkungan.

Pada fase desain pengguna, pengguna diminta membahas aspek-aspek desain non-teknis dari sistem dengan bimbingan penganalisis antara lain perancangan ERD, perancangan UML, dan perancangan antarmuka.

Pada fase konstruksi, setiap desain yang diciptakan dalam fase sebelumnya selanjutnya ditingkatkan untuk dilakukan pengkodean sistem dengan melakukan implementasi basis data dan program.

Pada fase pelaksanaan adalah dimana aplikasi baru dilakukan pengujian unit dan validasi serta pengenalan terhadap aplikasi.

\section{PERANCANGAN SISTEM}

\section{A. Analisis Kebutuhan Sistem}

Kebutuhan fungsional yang pertama yaitu sistem dapat melakukan diagnosis parameter lingkungan berupa karbon monoksida, nitrogen dioksida, partikulat, suhu, kelembapan udara, dan intensitas cahaya. Kedua, sistem memiliki fitur login untuk admin dan pembuat keputusan agar tidak semua pengguna dapat mengakses basis data. Ketiga, admin dapat mengelola data pengguna. Keempat, admin dan pembuat keputusan dapat mengelola data parameter yang digunakan sebagai masukan setiap parameter lingkungan. Kelima, admin dan pembuat keputusan dapat mengelola data baku mutu dan bobot yang digunakan sebagai masukan penghitungan rumus. Keenam, admin dan pembuat keputusan dapat mengelola data kriteria dan solusi yang digunakan sebagai keluaran penghitungan rumus. Pada kebutuhan fungsional yang terakhir, seluruh pengguna dapat melihat riwayat data indeks setiap harinya.

Selanjutnya untuk kebutuhan non-fungsional yang pertama yaitu sistem menggunakan kerangka kerja CodeIgniter. Kedua, sistem sebaiknya user-friendly. Ketiga, sistem dapat diakses dari perangkat komputer menggunakan penjelajah web. Keempat, sistem memiliki fitur konfirmasi dan pemberitahuan jika pengguna melakukan pengelolaan data baik menambah, mengubah, ataupun menghapus.

\section{B. Perancangan Teknis}

Spesifikasi perangkat keras yang digunakan untuk membangun sistem adalah prosesor Intel Core i5 $2.4 \mathrm{GHz}$, RAM 4 GB, dan HDD 500 GB. Sementara perangkat lunak yang digunakan adalah Windows 7, Apache, PHPMyAdmin dan MySQL, Sublime Text 2, serta penjelajah web.

\section{Perancangan ERD}

ERD digunakan untuk memodelkan data yang akan disimpan dalam basis data. Terdapat dua langkah yang dibutuhkan untuk melakukan perancangan sistem, yaitu menentukan entitas dan atribut data serta membuat diagram. Entitas dan atribut ditunjukkan pada Tabel 1.

\begin{tabular}{|c|c|c|c|}
\hline Entitas & Atribut & Tipe Data & Key \\
\hline \multirow{3}{*}{ Bamut } & bamutID & $\operatorname{int}(1)$ & primary \\
\hline & parameterID & varchar(1) & foreign \\
\hline & nilai & decimal $(7,2)$ & \\
\hline \multirow{3}{*}{ Bobot } & bobotID & $\operatorname{int}(1)$ & primary \\
\hline & parameterID & $\operatorname{varchar}(1)$ & foreign \\
\hline & nilai & decimal $(6,3)$ & \\
\hline \multirow{9}{*}{ Hariann } & id & $\operatorname{int}(4)$ & primary \\
\hline & node & $\operatorname{int}(2)$ & \\
\hline & tanggal & date & \\
\hline & HR_T & time & \\
\hline & HR_Q & $\operatorname{decimal}(3,1)$ & \\
\hline & HR_R & $\operatorname{decimal}(4,1)$ & \\
\hline & HR_N & $\operatorname{decimal}(3,1)$ & \\
\hline & HR_C & $\operatorname{int}(3)$ & \\
\hline & HR_P & $\operatorname{int}(4)$ & \\
\hline \multirow{4}{*}{ Indeks } & id & $\operatorname{int}(4)$ & primary \\
\hline & node & $\operatorname{int}(2)$ & \\
\hline & tanggal & date & \\
\hline & I & $\operatorname{Decimal}(3,2)$ & \\
\hline \multirow{4}{*}{ Kriteria } & id & $\operatorname{int}(1)$ & primary \\
\hline & $\min$ & $\operatorname{decimal}(3,2)$ & \\
\hline & $\max$ & $\operatorname{decimal}(3,2)$ & \\
\hline & keterangan & $\operatorname{varchar}(16)$ & \\
\hline \multirow{2}{*}{ Parameter } & parameterID & $\operatorname{varchar}(1)$ & primary \\
\hline & nama & $\operatorname{varchar}(20)$ & \\
\hline \multirow{3}{*}{ Pengguna } & userID & $\operatorname{varchar}(12)$ & primary \\
\hline & password & $\operatorname{varchar}(12)$ & \\
\hline & level & $\begin{array}{l}\text { enum(admin,pembuat } \\
\text { keputusan) }\end{array}$ & \\
\hline \multirow{8}{*}{ Solusi } & solusiID & $\operatorname{int}(1)$ & primary \\
\hline & kriteriaID & $\operatorname{int}(1)$ & foreign \\
\hline & sol_si & text & \\
\hline & sol_ec & text & \\
\hline & sol_ws & text & \\
\hline & sol_wr & text & \\
\hline & sol_tr & text & \\
\hline & sol_ed & text & \\
\hline
\end{tabular}

Diagram yang menggambarkan keseluruhan sistem ditunjukkan pada Gambar 1.

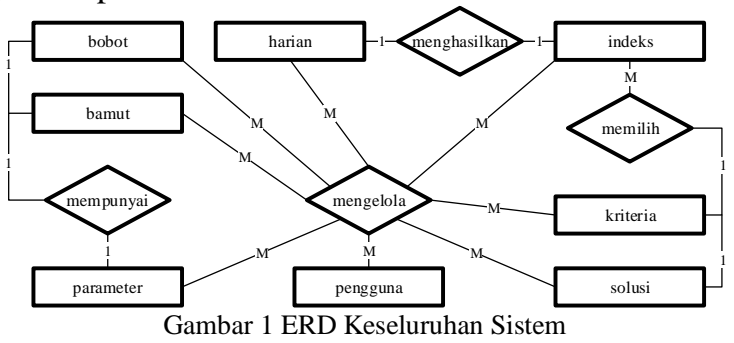

D. Perancangan UML

Perancangan UML memberikan ruang untuk mengembangkan detail fungsi yang dibutuhkan oleh sistem sebelum penulisan kode dimulai. Terdapat tiga diagram yang akan dirancang, yaitu diagram aktivitas, diagram use case, dan diagram sekuensial. Diagram aktivitas dan diagram use case ditunjukkan pada Gambar 2 dan Gambar 3. 


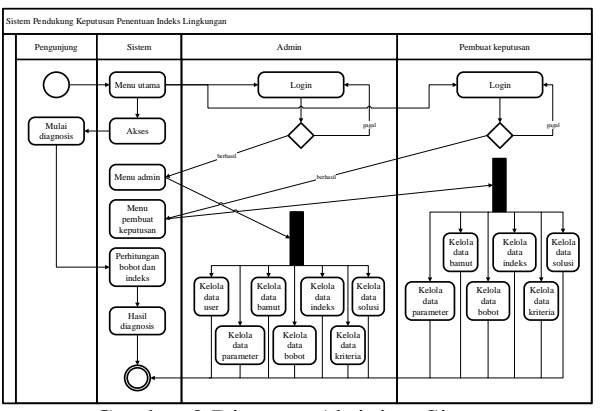

Gambar 2 Diagram Aktivitas Sistem

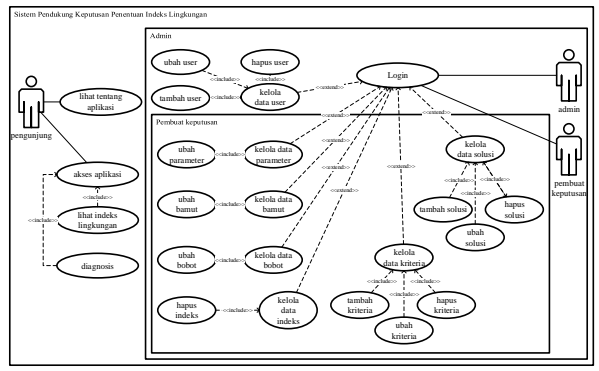

Gambar 3 Diagram Use Case Sistem

Berikut merupakan diagram sekuensial skenario login yang ditunjukkan pada Gambar 4, skenario melakukan dignosis yang ditunjukkan pada Gambar 5, skenario menambah pengguna yang ditunjukkan pada Gambar 6, skenario mengubah pengguna yang ditunjukkan pada Gambar 7, dan skenario menghapus pengguna yang ditunjukkan pada Gambar 8 .

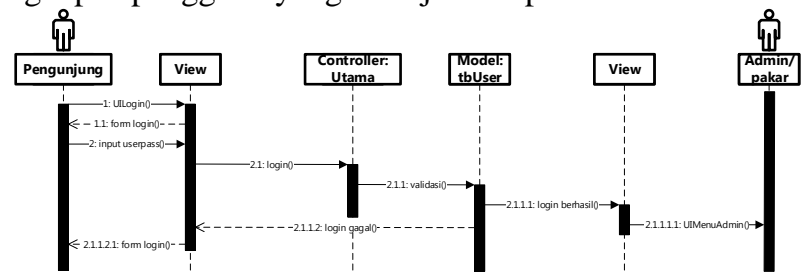

Gambar 4 Diagram Sekuensial Skenario Login

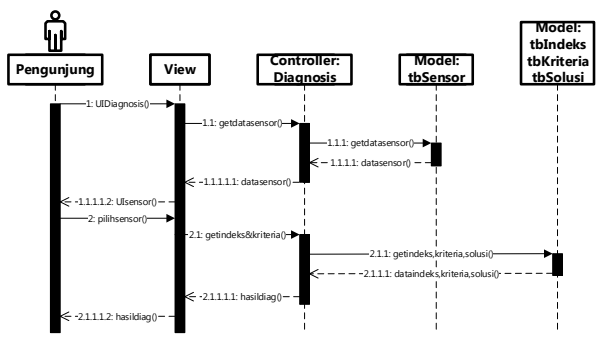

Gambar 5 Diagram Sekuensial Skenario Diagnosis

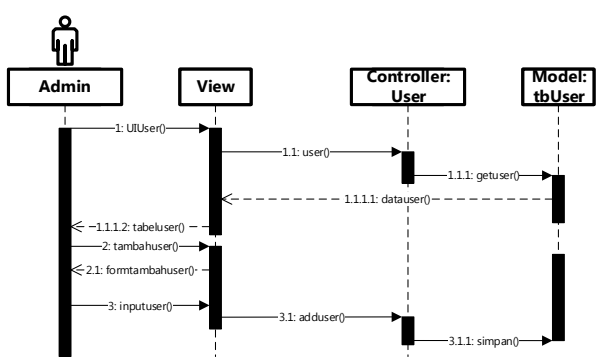

Gambar 6 Diagram Sekuensial Skenario Menambah Pengguna

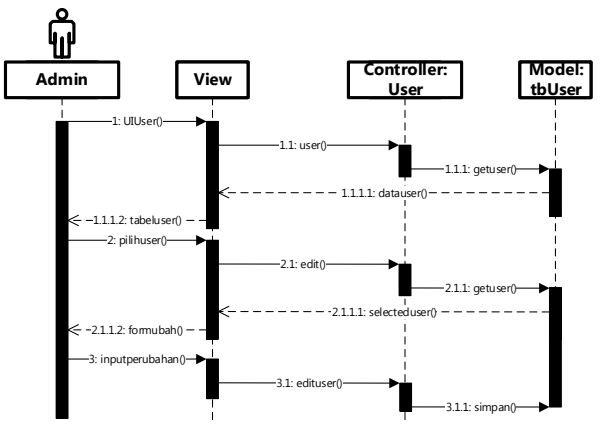

Gambar 7 Diagram Sekuensial Skenario Mengubah Pengguna

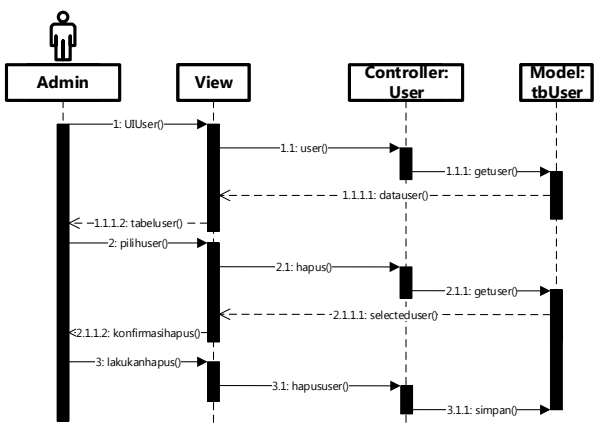

Gambar 8 Diagram Sekuensial Skenario Menghapus Pengguna

Skenario pada entitas kriteria dan solusi juga dapat menambah, mengubah, dan menghapus, sedangkan skenario pada entitas parameter, bamut, dan bobot hanya dapat mengubah, sementara skenario pada entitas indeks hanya dapat menghapus.

\section{E. Perancangan Antarmuka}

Desain antarmuka menu pengunjung, antarmuka form login, dan desain antarmuka menu admin/pembuat keputusan dapat dilihat pada Gambar 9, Gambar 10, dan Gambar 11.

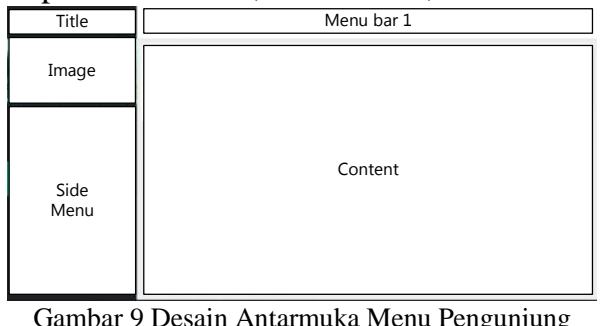

Gambar 9 Desain Antarmuka Menu Pengunjung

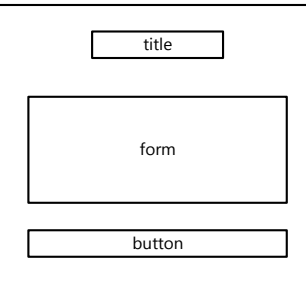

Gambar 10 Desain Antarmuka Form Login

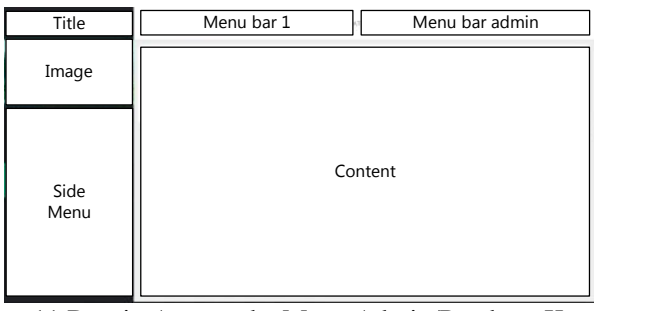




\section{IMPLEMENTASI DAN PENGUJIAN}

\section{A. Implementasi}

Proses implementasi dibagi menjadi implementasi basis data dan implementasi program. Terdapat tujuh tabel pada basis data antara lain, tabel pengguna yang ditunjukkan pada Tabel 2 , tabel parameter yang ditunjukkan pada Tabel 3, tabel bamut yang ditunjukkan pada Tabel 4, tabel bobot yang ditunjukkan pada Tabel 5, tabel kriteria yang ditunjukkan pada Tabel 6, tabel solusi yang ditunjukkan pada Tabel 7 , dan tabel indeks yang ditunjukkan pada Tabel 8.

Tabel 2 Struktur Tabel Pengguna

\begin{tabular}{|c|c|c|c|c|c|c|}
\hline & \# & Name & Type & Collation Attributes & Null & Default Extra \\
\hline$\square$ & 1 & username & $\operatorname{varchar}(12)$ & & No & None \\
\hline$\square$ & 2 & password & $\operatorname{varchar}(20)$ & & No & None \\
\hline$\square$ & 3 & level & enum('admin', 'pakar') & & No & None \\
\hline
\end{tabular}

Tabel 3 Struktur Tabel Parameter

\begin{tabular}{|c|c|c|c|c|c|c|}
\hline & $\#$ & Name & Type & Collation Attributes & Null & Default Extra \\
\hline$\square$ & 1 & parameterID & $\operatorname{varchar}(1)$ & & No & None \\
\hline & 2 & nama & varchar(20) & & No & None \\
\hline
\end{tabular}

Tabel 4 Struktur Tabel Bamut

\begin{tabular}{|lllll}
$\#$ & Name & Type & Collation Attributes Null Default Extra \\
\hline 1 & bamutlD & int(1) & No None AUTO_INCREMENT \\
$\square$ & 2 parameterlD & varchar(1) & No None \\
\hline 3 & nilai & decimal(7,2) & No None
\end{tabular}

Tabel 5 Struktur Tabel Bobot

\begin{tabular}{|c|c|c|c|c|c|c|c|}
\hline & \# & Name & Type & Collation Attributes & Null & Default & Extra \\
\hline$\square$ & 1 & bobotID & $\operatorname{int}(1)$ & & No & None & AUTO_INCREMENT \\
\hline$\square$ & 2 & parameterID & $\operatorname{varchar}(1)$ & & No & None & \\
\hline$\square$ & 3 & nilai & decimal $(6,3)$ & & No & None & \\
\hline
\end{tabular}

Tabel 6 Struktur Tabel Kriteria

\begin{tabular}{|c|c|c|c|c|c|c|}
\hline & \# & Name & Type & Collation Attributes & Null & Default Extra \\
\hline$\square$ & 1 & kriterialD & $\operatorname{int}(1)$ & & No & None \\
\hline$\square$ & 2 & $\min$ & $\operatorname{decimal}(3,2)$ & & No & None \\
\hline$\square$ & 3 & $\max$ & decimal $(3,2)$ & & No & None \\
\hline$\square$ & 4 & keterangan & $\operatorname{varchar}(13)$ & & No & None \\
\hline
\end{tabular}

Tabel 7 Struktur Tabel Solusi

\begin{tabular}{|c|c|c|c|c|c|c|}
\hline & $\#$ & Name & Type Collation & Attributes & Null & Default Extra \\
\hline$\square$ & 1 & solusilD & $\operatorname{int}(1)$ & & No & None \\
\hline$\square$ & 2 & kriterialD & $\operatorname{int}(1)$ & & No & None \\
\hline$\square$ & 3 & sol_si & text & & No & None \\
\hline$\square$ & 4 & sol_ec & text & & No & None \\
\hline$\square$ & 5 & sol_ws & text & & No & None \\
\hline$\square$ & 6 & sol_wr & text & & No & None \\
\hline$\square$ & 7 & sol_tr & text & & No & None \\
\hline$\square$ & 8 & sol_ed & text & & No & None \\
\hline
\end{tabular}

Tabel 8 Struktur Tabel Indeks

\begin{tabular}{|c|c|c|c|c|c|c|c|}
\hline & \# & Name & Type & Collation Attributes & Null & Default & Extra \\
\hline$\square$ & 1 & id & $\operatorname{int}(4)$ & & No & None & AUTO_INCREMENT \\
\hline$\square$ & 2 & node & $\operatorname{int}(2)$ & & No & None & \\
\hline$\square$ & 3 & tanggal & date & & No & None & \\
\hline$\square$ & 4 & indeks & decimal $(3,2)$ & & No & None & \\
\hline
\end{tabular}

Implementasi program adalah penerapan fungsi-fungsi program pada antarmuka program. Pada sistem terdapat beberapa antarmuka, yaitu menu utama ditunjukkan pada Gambar 12, menu indeks lingkungan ditunjukkan pada Gambar 13, menu diagnosis ditunjukkan pada Gambar 14, menu tentang aplikasi ditunjukkan pada Gambar 15, menu login ditunjukkan pada Gambar 16, menu admin dan menu pembuat keputusan ditunjukkan pada Gambar 17 dan Gambar 18, serta menu data pengguna ditunjukkan pada Gambar 19.
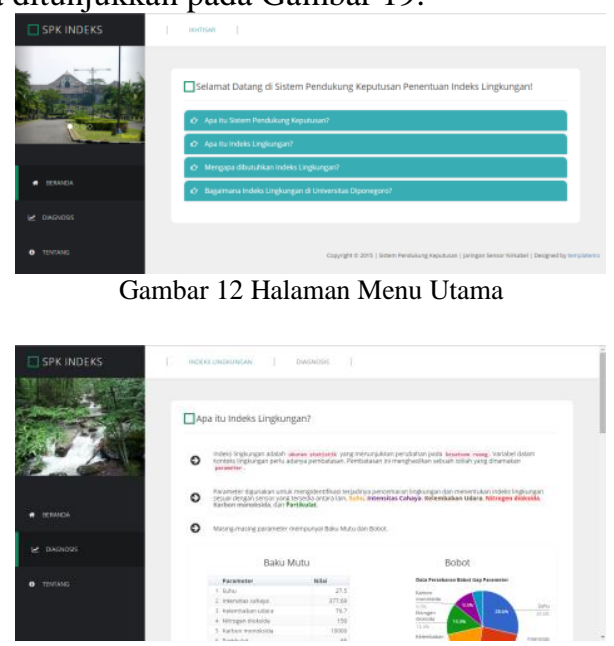

Gambar 13 Halaman Menu Indeks Lingkungan

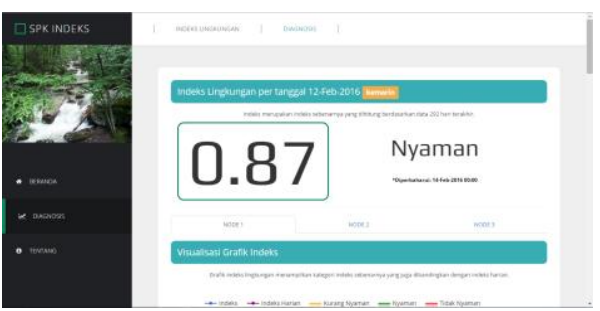

Gambar 14 Halaman Menu Diagnosis

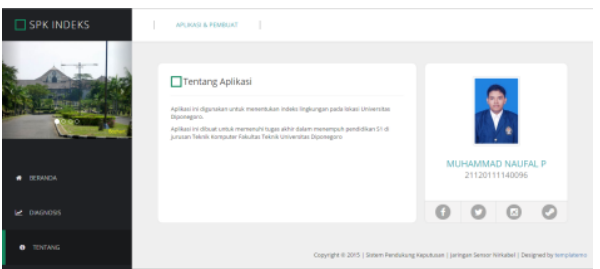

Gambar 15 Halaman Menu Tentang
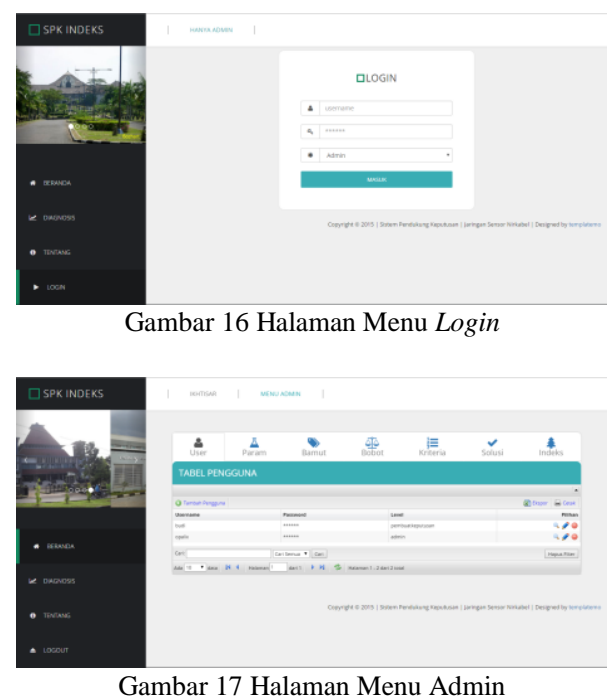

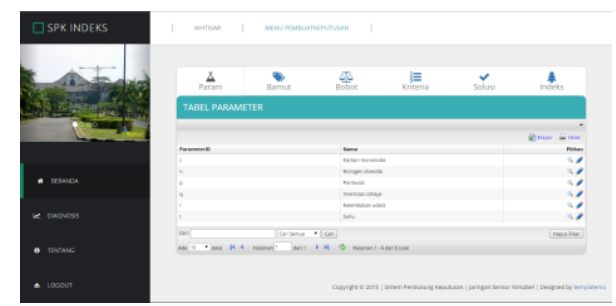

Gambar 18 Halaman Menu Pembuat Keputusan

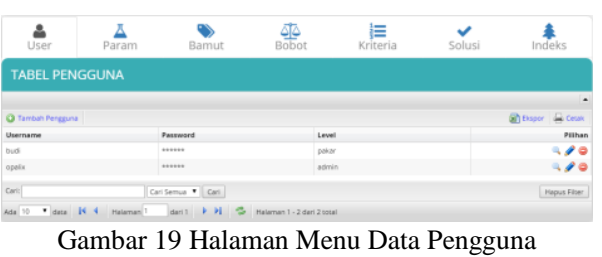

Pada menu data pengguna terdapat beberapa aksi untuk mengelola data, yaitu menambah, mengubah dan menghapus. Gambar 20 menunjukkan form untuk menambah pengguna. Gambar 21 menunjukkan form untuk mengubah pengguna, dan Gambar 22 menunjukkan konfirmasi untuk menghapus pengguna.
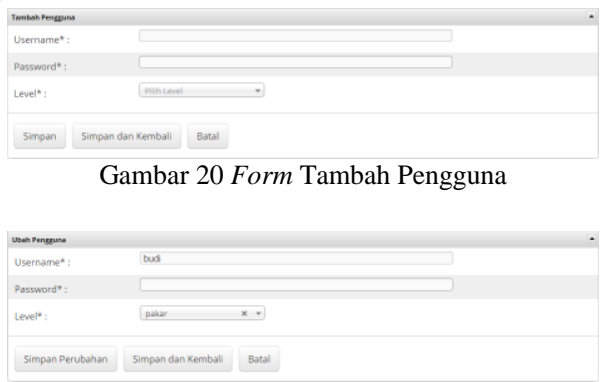

Gambar 21 Form Ubah Pengguna

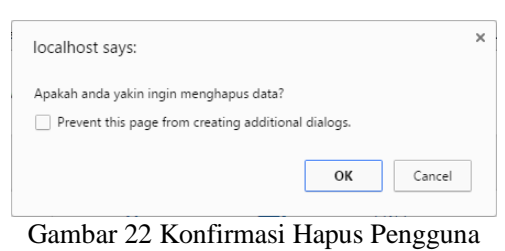

Pada menu kriteria dan solusi juga dapat menambah, mengubah, dan menghapus, sedangkan menu parameter, bamut, dan bobot hanya dapat mengubah, sementara menu indeks hanya dapat menghapus.

\section{B. Pengujian}

Pengujian unit adalah melakukan analisis dari masingmasing fungsi di dalam sistem. Tabel 9 dan Tabel 10 merupakan tabel pengujian aktivitas pengunjung dan tabel pengujian aktivitas admin/pembuat keputusan.

Tabel 9 Pengujian Aktivitas Pengunjung

\begin{tabular}{|l|c|}
\hline \multicolumn{1}{|c|}{ Pengujian } & Analisis \\
\hline Mengakses menu utama. & Berhasil \\
\hline Mengakses menu tentang aplikasi. & Berhasil \\
\hline Mengakses menu tentang indeks lingkungan & Berhasil \\
\hline Mengakses menu diagnosis. & Berhasil \\
\hline
\end{tabular}

Tabel 10 Pengujian Aktivitas Admin/Pembuat Keputusan

\begin{tabular}{|l|c|}
\hline \multicolumn{1}{|c|}{ Pengujian } & Analisis \\
\hline Melakukan login. & Berhasil \\
\hline Mengakses menu pengguna. & Berhasil \\
\hline Menambah data pengguna. & Berhasil \\
\hline Mengubah data pengguna. & Berhasil \\
\hline Menghapus data pengguna. & Berhasil \\
\hline
\end{tabular}

Tabel 10 Pengujian Aktivitas Admin/Pembuat Keputusan (lanjutan)

\begin{tabular}{|l|c|}
\hline Mengakses menu parameter. & Berhasil \\
\hline Mengubah data parameter. & Berhasil \\
\hline Mengakses menu baku mutu. & Berhasil \\
\hline Mengubah data baku mutu. & Berhasil \\
\hline Mengakses menu bobot. & Berhasil \\
\hline Mengubah data bobot. & Berhasil \\
\hline Mengakses menu kriteria. & Berhasil \\
\hline Menambah data kriteria. & Berhasil \\
\hline Mengubah data kriteria. & Berhasil \\
\hline Menghapus data kriteria. & Berhasil \\
\hline Mengakses menu solusi. & Berhasil \\
\hline Menambah data solusi. & Berhasil \\
\hline Mengubah data solusi. & Berhasil \\
\hline Menghapus data solusi. & Berhasil \\
\hline Mengakses menu indeks. & Berhasil \\
\hline Menghapus data indeks. & Berhasil \\
\hline
\end{tabular}

Pengujian validasi dilakukan untuk menguji apakah indeks yang ditampilkan sudah sesuai. Pengujian dilakukan dengan menggunakan data dummy. Data dummy dimasukkan ke dalam node 1 dan node 2 antara tanggal 2015-04-26 sampai dengan 2016-02-11 dengan jumlah data 292 hari. Indeks lingkungan yang ditampilkan ditunjukkan pada Gambar 23.

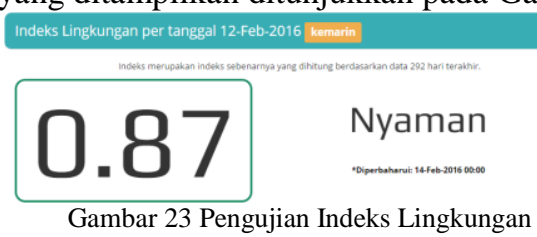

Untuk membuktikan apakah indeks yang ditampilkan valid, akan dilakukan penghitungan secara manual. Pertama, menghitung nilai skor harian $(\mathrm{Sc})$. Sc didapatkan dari membagi data harian (HR) dengan baku mutu. Berikut merupakan salah satu diagram garis sepuluh data dummy pertama nilai harian suhu (HR_T) dan nilai skor hariannya (Sc_T) pada node 1 dan node 2 yang ditunjukkan pada Gambar 24 dan Gambar 25.

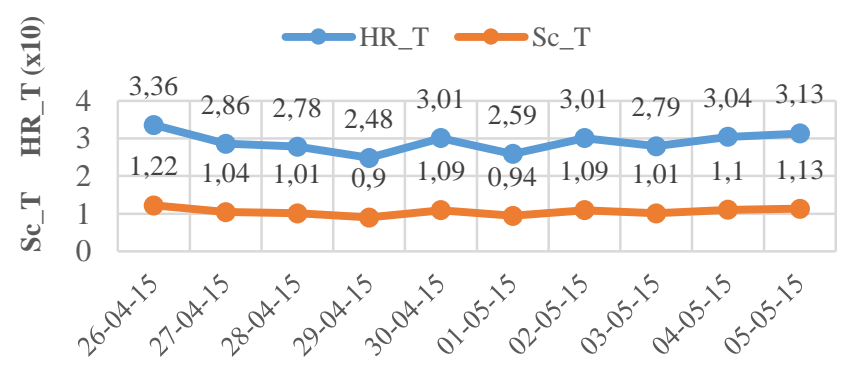

Gambar 24 Diagram Garis Sepuluh Data Dummy Pertama HR_T dan Sc_T pada Node 1

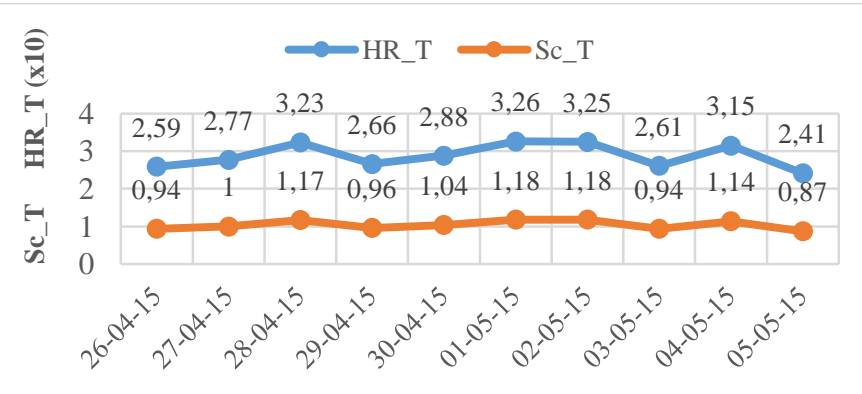

Gambar 25 Diagram Garis Sepuluh Data Dummy Pertama HR_T dan Sc_T pada Node 2

Kemudian menghitung rerata ukur skor harian (Scr) yang ditunjukkan pada Tabel 11. 
Tabel 11 Rerata Ukur Skor Harian (Scr)

\begin{tabular}{|c|r|r|r|r|r|r|}
\hline Node & \multicolumn{1}{|c|}{ Scr_T } & \multicolumn{1}{|c|}{ Scr_Q } & \multicolumn{1}{|c|}{ Scr_R } & \multicolumn{1}{c|}{ Scr_N } & \multicolumn{1}{c|}{ Scr_C } & \multicolumn{1}{c|}{ Scr_P } \\
\hline 1 & 1,01 & 0,95 & 0,99 & 0,71 & 0,33 & 0,80 \\
\hline 2 & 1,02 & 0,96 & 0,97 & 0,72 & 0,33 & 0,81 \\
\hline
\end{tabular}

Selanjutnya memilih node yang akan digunakan untuk menentukan indeks lingkungan dengan menggunakan metode SAW. Langkah-langkah penyelesaiannya adalah sebagai berikut.

Pertama, menentukan bobot dari tiap parameter. $W=[(0,286),(0,238),(0,19),(0,143),(0,095),(0,048)]$

Kedua, membuat matriks keputusan $(\mathrm{X})$ terhadap atribut

Scr.

$$
X=\left[\begin{array}{llllll}
1,01 & 0,95 & 0,99 & 0,71 & 0,33 & 0,80 \\
1,02 & 0,96 & 0,97 & 0,72 & 0,33 & 0,81
\end{array}\right]
$$

Ketiga, melakukan normalisasi matriks (X). Karena indeks yang akan ditampilkan adalah indeks yang tertinggi, maka pada normalisasi matriks menggunakan nilai maks dari tiap Scr.

$$
\begin{aligned}
& r_{11}=\frac{\text { Node } 1}{\operatorname{maks}(1,01 ; 1,02)}=0,9902 \quad r_{21}=\frac{1,02}{\operatorname{maks}(1,01 ; 1,02)}=1,0000 \\
& r_{12}=\frac{0,95}{\operatorname{maks}(0,95 ; 0,96)}=0,9896 \quad r_{22}=\frac{0,96}{\operatorname{maks}(0,95 ; 0,96)}=1,0000 \\
& r_{13}=\frac{0,99}{\operatorname{maks}(0,99 ; 0,97)}=1,0000 \quad r_{23}=\frac{0,97}{\operatorname{maks}(0,99 ; 0,97)}=0,9798 \\
& r_{14}=\frac{0,71}{\operatorname{maks}(0,71 ; 0,72)}=0,9861 \quad r_{24}=\frac{0,72}{\operatorname{maks}(0,71 ; 0,72)}=1,0000 \\
& r_{15}=\frac{0,33}{\operatorname{maks}(0,33 ; 0,33)}=1,0000 \quad r_{25}=\frac{0,33}{\operatorname{maks}(0,33 ; 0,33)}=1,0000 \\
& r_{16}=\frac{0,80}{\operatorname{maks}(0,80 ; 0,81)}=0,9877 \quad r_{26}=\frac{0,81}{\operatorname{maks}(0,80 ; 0,81)}=1,0000
\end{aligned}
$$

Dari hasil perhitungan maka didapatkan matriks ternormalisasi $\mathrm{R}$, yaitu:

$$
R=\left[\begin{array}{llllll}
0,9902 & 0,9896 & 1,0000 & 0,9861 & 1,0000 & 0,9877 \\
1,0000 & 1,0000 & 0,9798 & 1,0000 & 1,0000 & 1,0000
\end{array}\right]
$$

Terakhir, mengalikan dengan tiap bobot yang sudah ditentukan untuk mencari alternatif terbaik.

$$
\begin{aligned}
V_{1}= & (0,9902 \times 0,286)+(0,9896 \times 0,238)+(1,0000 \times 0,19)+ \\
& (0,9861 \times 0,143)+(1,0000 \times 0,095)+(0,9877 \times 0,048) \\
= & 0,9921 \\
V_{2}= & (1,0000 \times 0,286)+(1,0000 \times 0,238)+(0,9798 \times 0,19)+ \\
= & (1,0000 \times 0,143)+(1,0000 \times 0,286)+(1,0000 \times 0,286) \\
= & 0,9961
\end{aligned}
$$

Karena $\mathrm{V}_{2}$ yang merupakan nilai preferensi dari alternatif node 2 mempunyai nilai yang lebih besar dari nilai yang lain, maka dalam kasus ini node 2 akan digunakan sebagai penentu indeks lingkungan.

Terakhir, menjumlahkan semua nilai Scr pada node 2 yang masing-masing dikalikan dengan bobot $\left(\mathrm{w}_{\mathrm{j}}\right)$ tiap parameter sehingga menghasilkan indeks yang ditunjukkan pada Tabel 12.

Tabel 12 Hasil Pengujian Indeks

\begin{tabular}{|c|r|r|r|}
\hline Parameter & Scr & \multicolumn{1}{|c|}{ Wj } & Scr $\times$ Wj \\
\hline T & 1,02 & 0,286 & 0,288 \\
\hline Q & 0,96 & 0,238 & 0,226 \\
\hline R & 0,97 & 0,19 & 0,184 \\
\hline N & 0,72 & 0,143 & 0,102 \\
\hline C & 0,33 & 0,095 & 0,031 \\
\hline P & 0,81 & 0,048 & 0,038 \\
\hline \multicolumn{4}{|l}{ Indeks } \\
\hline
\end{tabular}

Dari pengujian di atas dapat disimpulkan bahwa indeks yang ditampilkan pada sistem sudah sesuai dengan indeks yang dihitung secara manual yaitu 0,87 .

\section{PENUTUP}

\section{A. Kesimpulan}

Berdasarkan hasil pengujian dan analisis sistem pendukung keputusan penentuan indeks lingkungan, maka dapat diambil kesimpulan sebagai berikut. Pertama, sistem pendukung keputusan penentuan indeks lingkungan ini dapat menentukan indeks lingkungan yang didapatkan dengan menggunakan metode Simple Additive Weighting. Kedua, metode Simple Additive Weighting yang diaplikasikan pada sistem ini digunakan untuk menentukan node mana yang nilai Scr-nya akan dikalikan dengan bobot tiap parameter, sehingga hanya ada satu indeks lingkungan yang ditampilkan pada sistem. Ketiga, penentuan indeks mempunyai jumlah minimum data sebanyak 292 data yang akan diolah pada penghitungan rata-rata ukur skor harian. Jika jumlah data tidak memenuhi, maka indeks tidak dapat ditentukan. Keempat, indeks lingkungan yang ditampilkan merupakan indeks terbaru per hari ini dan akan diperbaharui setiap harinya pada pukul 00.00. Kelima, dalam pengujian validasi yang dilakukan penghitungan indeks secara manual didapatkan hasil yang sesuai dengan indeks yang ditampilkan pada sistem.

\section{B. Saran}

Sehubungan dengan hasil pengujian dan analisis dari penelitian yang telah dilakukan, penulis memberikan dua saran yang dapat digunakan untuk pengembangan sistem sebagai berikut. Pertama, agar penentuan indeks lingkungan lebih baik, dapat ditambahkan beberapa parameter lagi sehingga kesimpulan mengenai keadaan lingkungan yang diukur dapat lebih akurat. Kedua, sistem dapat menentukan indeks lingkungan pada lokasi lainnya atau lebih luas lagi.

\section{DAFTAR PUSTAKA}

[1] Lukman, Rebeka, Damjan Krajnc dan Peter Glavič, "University ranking using research, educational and environmental indicators," Journal of Cleaner Production, vol. 18, pp. 619-628, May 2010.

[2] Sari, R.F., "Methodology and evaluation of green and sustainable campus indicators for world," Proceeding of the International Ranking Expert Group-6 (IREG6), 2012.

[3] Hazelkorn, Ellen, "World-class Universities or Worldclass Systems? Rankings and Higher Education," UNESCO Forum on Rankings and Accountability in Higher Education, 2011.

[4] Ghazali, A.A. Soebroto dan E. Suhartanto, "Sistem Pendukung Keputusan Penentuan Kualitas Air Sungai dengan Metode Fuzzy Mamdani," Jurnal Mahasiswa PTIIK UB, vol. 5, no. 6, 2015.

[5] Pressman, R.S., Rekayasa Perangkat Lunak, Yogyakarta: Andi, 2007.

[6] Kendall, K.E. dan J.E. Kendall, Analisis dan Perancangan Sistem, Jakarta: Prenhallindo, 2003. 